\title{
Canadian Shorts at Toronto 1997
}

By Patricia Thompson

Fall 1997 Issue of KINEMA

\section{THIRTY-ONE CANADIAN SHORT FILMS WERE SCREENED AT THE 1997 TORONTO INTERNATIONAL FILM FESTIVAL}

Here's a taste of the variety found in one screening during the Perspective Canada programme.

Across

Colour and B\&W, 4 min.

Incantation

B\&W, 5 min.

Director: Cara Morton

Two from the same director -- who is fond of quick-snap cutting. Across gives glimpses of a young woman swimming -- where? Apparently through memories of her life so far, to a place of survival, and all overlaid with a peaceful watery sounding track. Incantation uses the camera to record a protest march, the fast images softened by quiet interludes of a boy climbing a tree, a small girl whirling and dancing and people, talking and observing. Slight, ethereal, but too soft and wispy.

Museum

Director: Chris Walsh

B\&W, 8 min.

The narrator is a documentary filmmaker who tells of her brief encounter with David while shooting outside footage. Back in her apartment she shows him a film about her mother's wedding dress. When she awakes the next morning, David has gone leaving her a note and a film he made "while you were sleeping". You never see the filmmaker or David -- moments of blank screen are left for the viewer to fill in. Only David's film is left to watch. The film-made-during-the-night ending doesn't really work, and the whole needs more development.

Dance With $\mathrm{Me}$

Director: Cassandra Nicolaou

Colour, 9 min.

A slight, slow mixture of memory and dreams exposing a young woman grappling with her cultural background, her ailing mother and her feelings of guilt. Rather sleep-inducing...

Guise

Director: Wrik Mead

Colour, 9 min.

The woman emerges naked from the leafy ground and dons her medieval armour, piece by piece. The narration gives the background to this metaphorical, and amusing, examination of lesbian identity. The load of armour against the world eventually fells the woman to the ground! It's a pity that the voice of the narrator is not equal to the wry and witty words.

Linear Dreams

Animator: Richard Reeves

Colour, 7 min. $35 \mathrm{~mm}$

Hand-made images and sound, scratched on film, and heavily indebted to Norman McLaren. Having said that, Reeves has learned well from the Master -- producing rushing lines that transform into stellar constellations, to semi-realistic animals, and back again, slowing down now and then to give the eyes a few seconds of rest. Dazzling colours and a thumping heartbeat give the film a joyous feeling -- and it's all ready in 35mm for a commercial showing!

1919

Director: Noam Gonick 
$\mathrm{B} \& \mathrm{~W}, 8 \mathrm{~min}$.

The Winnipeg General Strike was in 1919, and this fictional account sets the Strike headquarters at Wong's Steam Bath and Barber Shop, where a broad spectrum of men meet for anonymous sex. Labour and gay history united! Filmed in the style of movies of the time, with intertitles and a Keystone Kops atmosphere, it's engaging, but only mildly entertaining.

The Mao Lounge

Director: Chad Derrick

$\mathrm{B} \& \mathrm{~W}, 48 \mathrm{~min}$.

The principal character, Jim, shares a loft with his photographer girlfriend, and a morose drummer. Jim wanders the street markets in his ethnic neighbourhood, and sits for hours in a local café watching the customers play chess and talk. He smokes endlessly, as do most of the people around him. He stares at the cityscape from his rooftop, he watches TV, he does nothing. Are we supposed to understand or perhaps emphathise with this empty life of a young man who can barely conduct a conversation, and who just marks time in a chillingly unconnected space? I cannot.

\section{Author Information}

Patricia THOMPSON (d. 1999) was Publisher and Editor of Film Canada Yearbook and Canadian Editor for the International Motion Picture Almanac and the International Television and Video Almanac (Quigley, NY). She was reviewing Canadian short films for several decades. 